\title{
TO THE DISCUSSION ON THE POLITICAL AND ADMINISTRATIVE STATUS OF THE BOSPORAN KINGDOM IN THE $10^{\mathrm{TH}}-12^{\mathrm{TH}}$ CENTURIES ${ }^{1}$
}

\author{
Valeriy E. Naumenko \\ Crimean Federal University named after V.I. Vernadsky, Republic of Crimea, Simferopol, Russian Federation
}

\begin{abstract}
A comprehensive analysis of the sources shows that during the 10th-12th centuries Bosporus, or Bosporan Kingdom, was an important strategic point of the Byzantine Empire in the Northern Black Sea. It performed the functions of a transit trade seaside centre on the south of Eastern Europe, the byzantine fortress on the border with the barbarian world, the residence of governor of the theme and archbishop of Bosporus. The article provides an overview of the main events of the political and administrative history of the Bosporus in the studied period. These include the issues of the end of the "Khazar period" in its history, the historical context and geography campaign of Khazar warlord Pesakh (about 935-941), the Old Russian princes Svyatoslav (965) and Vladimir (about 986-987), the revolt of the archon Georgy Tsula (about 1016) in Khazaria, date of establishment and limits of Tmutarakan principality, the theme Bosporus and byzantine katepanikion of Taurica, political and administrative status of the Bosporus in the 12th century.

Key words: Bosporus, Byzantine Empire, Khazar Khanate, Ancient Russia, theme, katepanikion, Pesakh, Tmutarakan principality, Georgy Tsula.
\end{abstract}

\section{К ДИСКУССИИ О ПОЛИТИКО-АДМИНИСТРАТИВНОМ СТАТУСЕ БОСПОРА В X-XII ВEКАX 1}

\author{
Валерий Евгеньевич Науменко \\ Крымский федеральный университет им. В.И. Вернадского, \\ Республика Крым, г. Симферополь, Российская Федерация
}

\begin{abstract}
Аннотация. Комплексный анализ источников показывает, что на протяжении X-XII вв. Боспор оставался важным стратегическим пунктом Византийской империи в Северном Причерноморье. Он выполнял функции приморского пункта транзитной торговли на юге Восточной Европы, византийской крепости на границе с варварским миром, резиденции правителя фемы и архиепископии Боспор. Статья посвящена обзору главных событий политической и административной истории Боспора в X-XII веках. К их числу относятся вопросы, связанные с завершением «хазарского периода» в его истории, исторический контекст и география походов хазарского «булшци» Песаха» (около 935-941 гг.), древнерусских князей Святослава (около 965 г.) и Владимира (около 986-987 гг.), мятеж архонта Хазарии Георгия Цулы (1016 г.), дата учреждения и территориальные пределы Тмутараканского княжества, фемы Боспор и византийского катепаната в Таврике, политикоадминистративный статус Боспора в XII веке.

Ключевые слова: Боспор, Византийская империя, Хазарский каганат, Древняя Русь, фема, катепанат, П글. Пмах, Тмараканское княжество, Георгий Цула.

На протяжении X-XII вв. Боспор являлся одним из ключевых стратегических пунктов Византийской империи в Северном Причерноморье, во многом обозначая здесь восточные пределы зоны влияния империи. Даже

немногочисленные и краткие упоминания письменных источников об истории городища в это время позволяют говорить о нем как о важном приморском пункте (порте), связанном с транзитной торговлей на юге Восточ-
\end{abstract}


ной Европы (Ибн Русте) [55, с. 670], византийской крепости на границах с варварским миром (Константин Багрянородный) [16, c. 52-53, 156-157, 171-177, 246-275], резиденции одноименной фемы, учрежденной не позднее 70-х гг. Х в., очевидно, в связи с ростом политической и территориальной экспансии Древнерусского государства в регионе (Эскуриальский Тактикон) [68, p. 266-269], и центре самостоятельной архиепископии [64, p. 273-274, 293-294, 345-346].

Тем не менее это лишь самые общие замечания о роли Боспора в политической жизни Северного Причерноморья в X-XII вв., не позволяющие пока воспроизвести целостную историческую картину. Причиной такого заключения, безусловно, является явный дефицит нарративных свидетельств об истории региона в интересующий нас период времени, что хорошо видно на примере крайне скудной историографии вопроса, сконцентрированной в основном лишь на отдельных сюжетах либо общих обзорах письменных источников по истории города и его округи $[5$, c. $118-120 ; 12$, c. $93-101 ; 13$, c. $235-236 ; 15$, c. $128-140 ; 17$, c. $132-133 ; 19$, c. $237-242 ; 20$, c. $93-96 ; 21$, c. $87-$ $92 ; 42$, c. 78-85; 66, p. 198-203; 70, p. 17-65].

На сегодняшний день прогресс в изучении истории Боспора X-XII вв. возможен лишь при условии расширения ее источниковой базы. При этом, занимаясь многие годы данной научной проблемой и хорошо представляя себе связанные с ее разработкой трудности, мы уверены, что такая работа должна идти одновременно в двух направлениях. Прежде всего, не ожидая открытия новых археологических объектов на территории городища, что, в принципе, всегда вероятно, но требует значительного времени для завершения исследований и введения в научный оборот их результатов, необходима максимально полная ревизия уже имеющихся архивных и фондовых музейных собраний вещественных источников, картографирование сохранившихся материальных объектов на территории Керчи, содержащих культурные горизонты или, по крайней мере, отдельные комплексы X-XII вв., что в целом даст возможность получить дополнительную информацию для обсуждения вопросов исторической топографии Боспора. Уже первые результаты такой источниковедческой работы, проделанной нами вместе с Л.Ю. Пономаревым, показали ее эффективность, позволив более предметно представить границы и архитектурно-топографические доминанты городища в X-XII вв. [32, с. 311-321; 41, c. 244-263], повторно «открыть» либо произвести реинтерпретацию ряда уже забытых в историографии памятников архитектуры и каменной пластики византийского Боспора [36, c. $275-288 ; 37$, с. 295-309], подвести некоторые промежуточные итоги изучения ранней хронологии церкви Святого Иоанна Предтечи, наиболее известного византийского храмового комплекса на территории исторической части Керчи [34, с. 325-331] ${ }^{2}$.

Другим направлением изучения истории Боспора X-XII вв. на сегодняшний день является ревизия сведений хорошо известных письменных источников, возможности анализа которых, как нам кажется, далеко не исчерпаны. При этом, ввиду их немногочисленности, необходимо широкое привлечение общих данных по истории взаимоотношений Византийской империи, Хазарского каганата и Древней Руси в пределах всего Северного Причерноморья, что даст возможность лучше оценить исторический контекст редких упоминаний Боспора в источниках для этого времени. Также следует обратить особое внимание на материалы сфрагистики, которые содержат важную дополнительную информацию о характере византийского присутствия и эволюции фемной модели управления в регионе.

Фонд опубликованных византийских печатей X-XII вв., происходящих с территории Боспора и соседнего Таманского городища, в последние годы значительно вырос и насчитывает уже около 90 моливдовулов [1, с. 564 $569 ; 52$, с. $364-369 ; 54$, с. $190 ; 57 ; 59$, c. $240-$ $250 ; 62$, p. 61-67] ${ }^{3}$. Подавляющее большинство из них происходит из акватории либо из раскопок Таманского городища, что, несомненно, указывает на его тесные политические, экономические и культурные связи с Византией. Относительно же небольшое количество византийских булл с территории Боспора, очевидно, связано с тем, что центр поселения этого периода в настоящий момент скрыт городской застройкой и портовой инфраструктурой, что не дает возможности вести его планомерные археологические исследования ${ }^{4}$. 
Именно введение в научный оборот большого числа сфрагистических находок, сопровождавшееся переосмыслением известных событий из истории Боспора, в хорошем смысле «спровоцировали» в историографии новый этап обсуждения интересующей нас проблематики $[2$, с. $7-13 ; 25$, с. 49-58; 30, c. $118-128 ; 38$, c. $165-187 ; 40$, c. $169-192 ; 47$, c. $157-163 ; 48$, c. $153-159 ; 49$, c. $368-375 ; 50$, c. 567-574; 60]. Однако в рамках этой дискуссии стало понятным, что практически все ключевые вопросы истории Боспора X-XII вв., к которым следует отнести - завершение «хазарского периода» в его истории, исторический контекст и географию походов хазарского «булшци» Песаха» (около 935-941 гг.), древнерусских князей Святослава (около 965 г.) и Владимира (около 986-987 гг.), мятеж архонта Хазарии Георгия Цулы (1016 г.), дату учреждения и территориальные пределы Тмутараканского княжества, фемы Боспор и византийского катепаната в Таврике, политикоадминистративный статус Боспора в XII в., требуют дальнейшего специального изучения.

В своей работе мы попытаемся выстроить возможный эскиз хронологии и последовательности событий, происходивших на берегах Керченского пролива на протяжении XXII вв., акцентируя внимание на политической принадлежности Боспора в тот или иной период времени. Наш анализ основан не только на известных данных нарративных свидетельств, но и, по возможности, привлекает хорошо стратифицированные археологические материалы. Такой комплексный подход при работе с источниками позволяет, как нам кажется, дать более объективную и разностороннюю оценку рассматриваемых событий.

О финале хазарского господства на Боспоре. Если не брать во внимание довольно сложный по задумке и, скорее всего, не реализованный Византией проект создания на полуострове фемы Климатов в 841 г. ${ }^{5}$, который был быстро заменен на более реальный по исполнению проект фемы Херсон около 860 г., то для Боспора существует довольно надежный хронологический репер для ответа на вопрос, когда хазарский военно-политический контроль в регионе сменился византийским - письмо патриарха Фотия к боспорскому архиепископу Антонию (около
873 г.) [69, S. 132]. Крещение последним местных иудеев, о чем восторженно сообщал Фотий в письме, в условиях свершившегося официального обращения хазар в иудаизм (не позднее 864 г.), было возможным только после размещения в городе византийской администрации и гарнизона ${ }^{6}$.

Данное заключение хорошо коррелируется с археологическими материалами (подробнее см.: [38, с. 175-179]). В конце IX - начале $\mathrm{X}$ в. прекращают функционирование подавляющее большинство салтово-маяцких поселений в Восточном Крыму, как, впрочем, и в других частях полуострова. При раскопках крупных городищ полуострова события эпохи иллюстрируют горизонты разрушения, выявленные археологически на Боспоре, а также в Партените и на Бакле в Южной Таврике. В Партените они датированы монетами Василия I (867-886) и Романа I Лакапина (920944). На Боспоре на месте разрушенной хазарской застройки в портовой части городища строится новый византийский квартал с прилегающей церковью Святого Иоанна Предтечи [22, с. 358-363, 382-383, 390-391].

Боспор для последней трети IX - середины X в., безусловно, является одним из византийских центров в Таврике. Ибн-Русте называет К-р-х (Керчь) византийским («румским») портом, для Ибн Хордадбеха и алФакиха Керченский пролив - западный предел Хазарского каганата [9, с. 35 ; 11, с. 124 ; 55 , с. 27]. Область Боспора входит в состав фемы Херсон, что следует из сопоставления данных Тактиконов Филофея (около 899 г.) и В.Н. Бенешевича (934-944 гг.), где эта фема упоминается как единственная византийская административная единица на полуострове, и трактатов Константина Багрянородного «О фемах» (934-944 гг.) и «Об управлении империей» (948-952 гг.), из сообщений которых ясен для фемы столичный статус Херсона и включение в состав провинции всей области Климатов, в том числе Боспора [16, с. 36-37, $52-53,156-157,174-175$; 63 , p. 98 ; 68 , p. $138-$ 139, 246-247].

Характеристика территориальной структуры фемы была бы не полной без привлечения, пусть и в качестве косвенного источника, нотиции времени второго патриаршества Николая I Мистика (912-925 гг.), перечисля- 


\section{ИСТОРИЯ, КУЛЬТУРА, ПРАВО В ВИЗАНТИЙСКИХ ПРОВИНЦИЯХ}

ющей архиепископии на территории полуострова (Херсон, Боспор, Сугдея, Готия и Фуллы), в том числе новосозданные в конце IX в. (Сугдея, Готия, Фуллы). Они охватывают все основные приморские и горные географические зоны полуострова, где влияние Византии было традиционно велико, и, таким образом, также определяют размеры фемного округа $[64, \text { p. } 273-274]^{7}$.

Наконец, показательными являются сведения Кембриджского Анонима (около 949 г.) о походе хазарского наместника Самкерца Песаха против жителей Таврики, состоявшемся между 935 и 941 гг. в ответ на спровоцированный ранее Византией набег «царя росов» Хельгу [8, с. 138-142]. Целью хазарской карательной акции были «города Романа», то есть императора Романа I Лакапина (920-941), что подчеркивает византийскую принадлежность полуострова в это время. Важное следствие войны - поход Руси на Константинополь в 941 г., который в историографии справедливо сопоставляется с известным походом князя Игоря древнерусских летописей. Поход Песаха остается, очевидно, последней зафиксированной в источниках попыткой хазар вмешаться в политическую историю Таврики ${ }^{8}$.

Русско-византийский кризис 935-941 гг. был исчерпан подписанием мирного договоpa 944 г., где при описании «Корсунской страны» подчеркивается ее византийская принадлежность и запрет русским вести здесь военные действия [43, с. 37, 234]. В целом определить статус и территорию «Корсунской страны» в нем не сложно. Топоним является древнерусской калькой официального названия византийской провинции на полуострове - фемы Херсон, зафиксированного в уже упомянутых тактиконах Филофея и В.Н. Бенешевича [68, p. 138-139, 246-247]. Географически она совпадает или близка области Климатов Константина Багрянородного, под которой подразумевались горные и прибрежные районы полуострова между Херсоном и Боспором [16, c. 36-37, 52-53, 156-157, 174-175]. В этой связи проблематичным выглядит аутентичность данных Пространной редакции Ответного письма хазарского царя Иосифа о западных пределах каганата в середине X в., где среди пунктов, определявших их, присутствует местность К-р-ц (Керчь) [14, с. 102]. Скорее все- го, эти сведения следует отнести к более раннему времени (концу VIII - началу IX в.), когда территориальная экспансия хазар в Крыму была максимальной [33, с. 546].

О русских походах 60-80-х гг. $\mathrm{X}$ в. в Крым и Приазовье. В данном случае речь идет о «восточном» походе князя Святослава 965 г. против Саркела, ясов и касогов в Приазовье и «корсунском» походе князя Владимира. Последний ныне датируется около 986987 гг. [40, с. 189], хорошо укладывается в русло в целом прогерманской и антивизантийской политики Руси в период княжения Ярополка (972-978) и первое десятилетие правления его брата, князя Владимира [28, с. 393424, 433-434]. Взятие Херсона становится причиной заключения династийного русско-византийского союза в Киеве, условием которого является крещение Руси и участие русского военного корпуса в подавлении мятежа Варды Фоки в Малой Азии в 988-989 годах 9 .

В контексте политико-административной истории Боспора этого времени следует отметить ряд моментов. Во-первых, «восточный поход» Святослава 965 г., который фактически стал финалом существования Хазарского каганата и максимально приблизил Древнерусское государство к границам византийской провинции в Таврике, вынудил Византию выделить из состава фемы Херсон отдельную фему на Боспоре. Впервые она присутствует в Эскуриальском тактиконе, составленном в 70-е гг. Х века [68, p. 255-261, 268-269]. Появление фемы объясняется не только общими процессами в административно-провинциальной истории Византии второй половины $\mathrm{X}$ в., когда на смену крупным фемам «ромейского» типа приходят малые фемы «армянского» типа, но и необходимостью усилить оперативность принятия решений местным стратигом, подчиненным непосредственно Константинополю.

Во-вторых, «Корсунский поход» Владимира, судя по данным современной археологии, имел значительно более широкую географию, чем принято думать, ориентируясь на сообщения древнерусских источников. В последние годы, вероятно, синхронные между собой «слои пожаров» $60-\mathrm{x}$ - начала $80-\mathrm{x}$ гг. $\mathrm{X}$ в. были обнаружены в Сугдее (датирован монетами Константина VII Багрянородного 
945-959 гг. выпуска), Алустоне (с монетой Никифора Фоки 963-969 гг.) и на Таматархе (с монетой Иоанна Цимисхия 969-976 гг.) [4, c. $128-129 ; 27$, с. $124 ; 45$, с. $147 ; 58$, c. 286$]$. Логично предположить, что и на Боспоре эти события должны были найти свое отражение в стратиграфии городища, хотя пока нам известны только пожары конца IX и конца XII в. из раскопок в его портовой части [23, с. 144].

В-третьих, после похода Владимира в самом конце X в. из состава Херсонской фемы, вероятно, выделяются фема Сугдея, известная по печатям ее стратигов первой половины XI в. [53, с. 187] и турмархия Готия. С последней связаны две печати ее турмарха [1, c. 566] и надпись с именем топотерита Цулы на Мангупе 994-995 гг., указывающая на появление византийского гарнизона на городище в это время [6, с. 262-271].

Наконец, в-четвертых, при Владимире в конце X в. либо в самом начале XI в., но не позднее 1015 г., на Таманском полуострове появляется древнерусское Тмутараканское княжество. Его статус (самостоятельное княжество либо союзная территория под протекторатом русских князей) и первые годы существования остаются предметом дискуссии в современной историографии [7, с. 155-165; 59, с. 258-259]. Однако в любом случае территория княжества не распространялась на европейский Боспор.

Боспор первой половины XI в., вероятно, продолжает оставаться столицей одноименной фемы. Правда, прямых указаний этому немного - печати, принадлежащие протоспафарию Боспора Георгию Цуле (должность в легенде моливдовула не сохранилась) и стратигу Боспора Аркадию [10, с. 95; 46, с. 70].

С именем Георгия Цулы, в контексте истории Боспора и Тмутараканского княжества, связана заметка Иоанна Скилицы об отправке императором Василием II в январе 1016 г. в Хазарию флота во главе с экзархом Монгом, сыном Андроника Дуки Лида, который вместе со Сфенгом, братом русского князя Владимира, подчинил эту страну, а ее архонта Георгия Цулу пленил в первом же сражении. «Монг» («Хриплый») - прозвище полководца времени Василия II Варды Фоки $[26$, c. 50-51]. Главный вопрос идущей в историографии дискуссии относительно отрывка
Иоанна Скилицы касается локализации упомянутой им области Хазарии - в Восточном Крыму (В.В. Майко, Н.А. Алексеенко), в пределах Керченского и Таманского полуострова (В.П. Степаненко, В.Н. Чхаидзе) или же Северо-Восточного Причерноморья (В.Е. Науменко, Ю.М. Могаричев) ${ }^{10}$. Если располагать Хазарию Скилицы в восточной части Крымского полуострова либо расширять ее территорию в восточном направлении, в таком случае Боспор времени мятежа оказывается вне зоны византийского влияния. Если же помещать указанные события исключительно на Таманском полуострове, то объяснения требует сам факт ведения военных действий Византией на территории формирующегося Тмутаранского княжества.

На наш взгляд, по имеющимся сведениям письменных источников X-XI вв., нет оснований пытаться локализовать Хазарию в пределах Крымского полуострова. Особое внимание стоит уделить сопоставлению топонимики указанных сочинений Константина Багрянородного с топонимической частью легенды известных печатей тмутараканского князя Олега-Михаила 1083-1094 гг. выпуска. Для первого к востоку от византийской Таврики, области Климатов, располагаются Таматарха, Зихия и Хазария [16, с. 41, 53, 157 , 175]. На всех моливдовулах князя Олега периода 1083-1094 гг. он назван архонтом «Матрахи, Зихии и всей (!) Хазарии» либо архонтом и дукой «Таматархи и всей (!) Хазарии» (сводку печатей см.: [40, с. 191]). Следовательно, топоним «Хазария» включает в широком смысле территории Северо-Восточного Причерноморья, в том числе и более узкие географические понятия Таматарха и Зихия, но не имеет никакого отношения к Таврике.

По справедливому замечанию В.П. Степаненко, титул Георгия Цулы («архонт») в момент мятежа, а также ярко выраженный антивизантийский характер восстания позволяют причислить главу мятежников к числу варварских правителей на границах империи, имевших союзные с ней отношения [51, с. 34].

О времени образования и территории византийского катепаната в Таврике. На сегодняшний день существует ряд хронологически точных свидетельств об образовании византийского катепаната в регионе 
около середины XI в. и его функционировании примерно до рубежа XI-XII веков. Эта реформа происходит не ранее 1059 г., на что указывает известная строительная надпись Льва Алиата, стратига еще объединенной фемы Херсона и Сугдеи [18, с. 15-19]. Но уже под 1066 г. «Повесть Временных лет» сообщает об отравлении тмутараканского князя-изгоя Ростислава херсонским «котопаном» [43, с. 111]. Из этого сообщения ясно, что византийский катепанат в регионе к этому времени существует, но в его состав еще не входят области, расположенные восточнее Таврики.

Ситуация изменяется в самом конце XI в., о чем свидетельствует недавно опубликованная печать Никифора Алана, катепана Херсона и Хазарии [2, с. 8-9]. С учетом союзного для Византии статуса Тмутараканского княжества в период правления князя Олега (1083-1094 гг.) (легенды его моливдовулов - «архонт Матрахи, Зихии и всей Хазарии» либо «архонт и дука Таматархи и всей Хазарии»), логичнее отнести датировку печати Никифора Алана к несколько более позднему времени. Таким образом, после 1094 г. византийский катепанат включил в свой состав и Таманский полуостров.

Здесь небезынтересно привести два косвенных источника в пользу данной гипотезы - энкомий Мануила Страворомана в честь Алексея I Комнина о территориальных приобретениях императора «на Боспоре Киммерийском» в период 1094-1105 гг. и письмо болгарского архиепископа Феофилакта (рубежа XI-XII вв.) об угрозе для «греческих городов между Танаисом и Меотидой» [12, c. $96 ; 19$, с. 239].

Политико-административный статус Боспора в XII в. остается до конца не ясным. Понятно лишь, что территория Боспора Киммерийского, по крайней мере, сам Боспор и Таматарха, находятся под контролем византийской администрации, но не более того. Сведения Иоанна Цеца (40-е гг. XII в.), Михаила Ритора (1153 г.), Михаила Хониата (1182 г.) слишком неопределенны, чтобы реконструировать административную систему управления в регионе $[12$, с. $96-101 ; 13$, c. 235-236]. Византийско-генуэзские договоpa 1169 и 1192 гг. лишь указывают на то, что города Боспор (Русия) и Таматарха включе- ны в состав империи [67, p. 35; 65, S. 255-256, № 1488]. Однако появлениелюбой новой сфрагистической либо эпиграфической находки может неожиданно быстро перевернуть наши нынешние представления об административной модели управления Византии на Европейском и Азиатском Боспоре.

\section{ПРИМЕЧАНИЯ}

${ }^{1}$ Статья представляет собой развернутый и существенно дополненный вариант доклада, прочитанного в программе XXVII Научных чтений памяти члена-корреспондента АН СССР В.Т. Пашуто (г. Москва, 15-17 апреля 2015 г.) [35, с. 212-216]. Ее отдельные положения также были озвучены в докладе в программе XXI Всероссийской научной сессии византинистов (г. Белгород, 20-23 апреля 2016 г.) [29, с. 154-156].

${ }^{2}$ Наиболее полный обзор истории изучения церкви Иоанна Предтечи см.: [44, с. 272-295]. Следует также отметить, что историческая топография Боспора X-XII вв. впервые в историографии стала предметом специального исследования. До этого единственным, но далеко не полным, обзором археологических памятников этого времени на территории Керчи являлась работа Т.И. Макаровой [24, c. $68-73]$.

3 Всего в каталоге византийских печатей из Тамани, опубликованных недавно В.Н. Чхаидзе, насчитывается 95 моливдовулов с общей датой в пределах VI-XIII веков. Из них 78 булл относится к периоду конца IX/начала X - XII в. [57, № 1-16, 1920, 24-37, 39-40, 46-63, 67-81]. Еще пять печатей, найденных в Керчи, происходят из коллекции Н.П. Лихачева Государственного Эрмитажа [52, с. 364-369], одна хранится в фондах Керченского музея-заповедника [1, с. 566-567]. К этому следует добавить обнаруженные ранее в Херсоне моливдовулы спафария Боспора Георгия Цулы начала XI в. $[46$, c. 70$]$ и боспорских епископов Луки, Георгия и Николая конца IX - второй половины Х в. [3, с. 132134], а также хранящуюся в Афинах буллу протоспафария и стратига Боспора Аркадия конца X начала XI века [10, с. 95].

${ }^{4}$ О границах, топографии и известных памятниках Боспора X-XII вв. подробно см.: [32, с. 312$318 ; 41$, c. $244-254]$.

${ }^{5}$ О феме Климатов, дискуссии в отношении даты ее образования и содержании этой византийской административной реформы в Таврике см. подробнее: [31, с. 689-698; 39, с. 476-485; 56, с. 312321; 72, p. 211-222].

${ }^{6}$ О дате обращения хазар в иудаизм см. подробнее: [61, p. 13-32; 71, p. 237-270]. 
7 Анализ территориальных пределов и структуры фемы Херсон конца IX - первой половины $\mathrm{X}$ в., в состав которой входила область Боспора, производился нами неоднократно. См.: [38, с. 173-174; 39 , с. $485-486 ; 40$, с. $174-175]$.

${ }^{8}$ Сюжет с походом Песаха, в том числе и историография вопроса, подробно разобран нами в специальной статье. См.: [30, с. 122-127].

${ }^{9}$ См. подробнее: [40, с. 186-190].

10 Полная историография вопроса изложена в недавней работе В.Н. Чхаидзе [60, с. 21-23, 29-37].

\section{СПИСОК ЛИТЕРАТУРЫ}

1. Алексеенко, Н. А. Византийская администрация на Боспоре во второй половине Х в. (по данным памятников сфрагистики) / Н. А. Алексеенко // Материалы по археологии, истории и этнографии Таврии. - 2006. - Вып. ХІІ. - С. 564-570.

2. Алексеенко, Н. А. Катепанат в Таврике: легендарные свидетельства или исторические реалии / Н. А. Алексеенко, Ю. А. Цепков // Херсонесский сборник. - Севастополь : СПД Арефьев, 2012. Вып. XVII.-C. 7-17.

3. Алексеенко, Н. А. Моливдовулы боспорских епископов из Херсона / Н. А. Алексеенко // Проблемы религий стран черноморско-средиземноморского региона. - Севастополь : ХГИКЗ, 2001.C. 131-138.

4. Баранов, И. А. Византийские монеты середины Х в. из Сугдеи / И. А. Баранов, В. В. Майко // STRATUM plus. - 1999. - № 6. - C. 128-129.

5. Болгов, Н. Н. Боспор византийский: очерки истории / Н. Н. Болгов // Проблемы истории, филологии и культуры. - 1998. - Вып. VI. - С. 116-123.

6. Виноградов, А. Ю. Надпись из Табана-дере: пятьсот лет спустя / А. Ю. Виноградов // Античная древность и средние века. - 2009. - Вып. 39. - С. 262-271.

7. Гадло, А. В. Предыстория Приазовской Руси. Очерки истории русского княжения на Северном Кавказе / А. В. Гадло. - СПб. : Изд-во СПбГУ, 2004. $-362 \mathrm{c}$.

8. Голб, Н. Хазарско-еврейские документы Х века / Н. Голб, О. Прицак ; науч. ред., коммент. В. Я. Петрухина. - М. ; Иерусалим : Гешарим, 1997. $-240 \mathrm{c}$.

9. Древняя Русь в свете зарубежных источников. Хрестоматия. Т. III. Восточные источники / Т. Н. Джаксон, И. Г. Коновалова, В. Я. Петрухин, Т. М. Калинина, А. В. Подосинов ; под ред. Т. Н. Джаксон, И. Г. Коноваловой, А. В. Подосинова. - М. : Русский фонд содействия образованию и науке, 2009. - 264 с.

10. Зайбт, Н. Печати стратигов византийской фемы Херсон / Н. Зайбт, В. Зайбт // Античная древ- ность и средние века. - 1995. - Вып. 27 : Византия и средневековый Крым. - С. 91-97.

11. Ибн Хордадбех. Книга путей и стран / Ибн Хордадбех ; пер. Н. Велихановой. - Баку : Элм, 1986. $-428 \mathrm{c}$.

12. Каждан, А. П. Византийский податной сборщик на берегах Киммерийского Боспора в конце XII в. / А. П. Каждан // Проблемы общественно-политической истории России и славянских стран. - М. : Изд-во Восточной литературы, 1963. - С. 93-101.

13. Каждан, А. П. Неизвестное греческое свидетельство о русско-византийских отношениях в XII в. / А. П. Каждан // Феодальная Россия во всемирно-историческом процессе : сб. ст., посвящ. Л. В. Черепнину. - М. : Наука, 1972. - С. 235-236.

14. Коковцов, П. К. Еврейско-хазарская переписка в Х в. / П. К. Коковцов. - Л. : Изд-во АН СССР, 1932. $-134 \mathrm{c}$.

15. Коновалова, И. Г. Город Росия/Русийа в XII в. / И. Г. Коновалова // Византийские очерки. СПб. : Алетейя, 2001.- С. 128-140.

16. Константин Багрянородный. Об управлении империей / под ред. Г. Г. Литаврина, А. П. Новосельцева. - М. : Наука, 1991. - 496 с.

17. Кулаковский, Ю. А. К истории Боспора Керчи в ХІ-ХІІ вв. / Ю. А. Кулаковский // Труды ХІ Археологического съезда в Киеве в 1899 г. Т. 2. М. : Печатня А. И. Снегиревой, 1902. - С. 132-133.

18. Латышев, В. В. Сборник греческих надписей христианских времен из Южной России / В. В. Латышев. - СПб. : Тип. Императорской академии наук, 1896. - 143 с.

19. Литаврин, Г. Г. Новые сведения о Северном Причерноморье (XII в.) / Г. Г. Литаврин // Феодальная Россия во всемирно-историческом процессе : сб. ст., посвящ. Л.В. Черепнину. - М. : Наука, 1972. - C. 237-242.

20. Майко, В. В. К вопросу о выделении средневековых горизонтов Боспора второй половины X-начала ХІ в. / В. В. Майко // 175 лет Керченскому музею древностей : материалы Междунар. конф. Керчь : КГИКЗ, 2001. - С. 93-96.

21. Майко, В. В. К вопросу о хазарах на Боспоре во второй половине Х в. / В. В. Майко // Пантикапей - Боспор - Керчь - 26 веков древней столицы. Керчь : КГИКЗ, 2000. - С. 87-92.

22. Макарова, Т. И. Археологические раскопки в Керчи около церкви Иоанна Предтечи / Т. И. Макарова // Материалы по археологии, истории и этнографии Таврии. - 1998. - Вып. VI. - С. 344-393.

23. Макарова, Т. И. Боспор - Корчев по археологическим данным / Т. И. Макарова // Византийская Таврика. - Киев : Наукова Думка, 1991. - С. 121-146.

24. Макарова, Т. И. Крым в Х - первой половине XIII в. Боспор - Корчев // Археология. Крым, Северо-Восточное Причерноморье и Закавказье в 
эпоху средневековья. IV-XIII века. - М. : Наука, 2003. - C. 68-73.

25. Могаричев, Ю. М. О «Крымской Хазарии» в XI-XII вв. / Ю. М. Могаричев // Княжа доба: історія і культура. - Львів : НАНУ, 2013. - Вип. 7. - С. 49-58.

26. Мохов, А. С. К просопографии византийской Таврики в XI в.: Варда Дука / А. С. Мохов // I Бахчисарайские научные чтения памяти Е.В. Веймарна : тезисы докладов и сообщений. - Бахчисарай : БИКЗ, 2012.- С. 50-51.

27. Мыц, В. Л. Находки золотых византийских монет из раскопок Алустона / В. Л. Мыц, С. Б. Адаксина // STRATUM plus. - 1999. - № 6. - C. 123-127.

28. Назаренко, А. В. Древняя Русь на международных путях: междисциплинарные очерки культурных, торговых, политических связей IX-XII вв. / А. В. Назаренко. - М. : Языки русской культуры, 2001.-784 c.

29. Науменко, В. Е. Византийский Боспор в Х в.: политико-административный аспект / В. Е. Науменко // Империя ромеев во времени и пространстве: центр и периферия : тез. докл. XXI Bсерос. науч. сессии византинистов. - М. ; Белгород : ООО «Эпицентр», 2016. - С. 154-156.

30. Науменко, В. Е. К военно-политической истории Таврики Х в.: русско-византийский конфликт 935-941 гг. и так называемый «поход Песаха» / В. Е. Науменко // Хазарский Альманах. - 2014. T. 12. - C. 118-134.

31. Науменко, В. Е. К вопросу о названии и дате учреждения византийской фемы в Таврике / В. Е. Науменко // Материалы по археологии, истории и этнографии Таврии. - 1998. - Вып. VI. C. 689-700.

32. Науменко, В. Е. К вопросу о территории и археологических памятниках Боспора - Керчи XХІІ вв. / В. Е. Науменко, Л. Ю. Пономарев // Х Боспорские чтения «Боспор Киммерийский и варварский мир в период античности и средневековья. Актуальные проблемы». - Керчь : КОИВ НАНУ, 2009. - C. 311-321.

33. Науменко, В. Е. К вопросу о характере византийско-хазарских отношений в конце VIII - середине IX в. / В. Е. Науменко // Проблемы истории, филологии, культуры. - 2002. - Вып. ХІІ. - С. 544-568.

34. Науменко, В. Е. К дискуссии о времени строительства церкви Иоанна Предтечи в Керчи: историографический экскурс / В. Е. Науменко, Л. Ю. Пономарев // XVII Боспорские чтения «Боспор Киммерийский и варварский мир в период античности и средневековья. Исследователи и исследования». - Керчь : НИЦ ИАК КФУ, ЦАИ БФ «Деметpa», 2016. - С. 325-331.

35. Науменко, В. Е. К дискуссии о политикоадминистративном статусе Боспора в X-XII вв. / В. Е. Науменко // XXVII Чтения памяти члена-кор- респондента АН СССР В.Т. Пашуто «Восточная Европа в древности и средневековье. Государственная территория как фактор политогенеза». - М. : ИВИ РАН, 2015. - С. 212-216.

36. Науменко, В. Е. К изучению исторической топографии средневековой Керчи: византийская каменная икона из «Нового Карантина» / В. Е. Науменко, Л. Ю. Пономарев // Античная древность и средние века. - 2015. - Вып. 43. - С. 275-288.

37. Науменко, В. Е. К исторической топографии Боспора X-XII вв.: об обстоятельствах находки и местоположении так называемой «церкви Шевелева» («церкви 1833 г.») / В. Е. Науменко, Л. Ю. Пономарев // Нартекс. Byzantina Ukrainensis. - Харьков : Майдан, 2013. - Т. 2. - С. 295-309.

38. Науменко, В. Е. Некоторые ключевые вопросы истории Таврики X-XI вв.: политико-административный аспект / В. Е. Науменко // Античная древность и средние века. - 2011. - Вып. 40. - С. 165-188.

39. Науменко, В. Е. От фемы Климатов к феме Херсон: особенности византийской военно-административной модели в Таврике в середине IX начале Х в. / В. Е. Науменко // Древнейшие государства Восточной Европы. 2014 год. Древняя Русь и средневековая Европа: возникновение государств. М. : Русский фонд содействия образованию и науке, 2016. - С. 475-506.

40. Науменко, В. Е. Таврика в системе руссковизантийских отношений середины X-XI в. (историко-археологический комментарий) / В. Е. Науменко // XEP $\Sigma \Omega N O \Sigma$ ӨEMATA: «империя» и «полис». Севастополь : СПД Арефьев, 2013. - С. 169-206.

41. Науменко, В. Е. Христианские памятники и топография Боспора X-XII вв. / В. Е. Науменко, Л. Ю. Пономарев // Климентовский сборник : материалы VI Междунар. конф. «Церковная археология: Херсонес - город святого Климента». - Севастополь : Телескоп, 2013. - С. 244-263.

42. Плахонін, А. Русь на Боспорі в ХІІ столітті / А. Плахонін // Крим в історичних реаліях України. - Київ : Інститут історії НАНУ, 2004. - С. 78-85.

43. Повесть временных лет. Ч. I / пер. Д. С. Лихачева, Б. А. Романова. - М. ; Л. : Изд-во АН СССР, 1950. $-406 \mathrm{c}$.

44. Пономарев, Л. Ю. Керченская церковь Иоанна Предтечи (историографический обзор) / Л. Ю. Пономарев, Д. В. Бейлин, С. А. Бейлина // Научный сборник Керченского заповедника. Симферополь : Бизнес-Информ, 2014. - Вып. IV. C. 272-306.

45. Сазанов, А. В. К дискуссии о так называемом походе Песаха в Крым: археологический аспект / А. В. Сазанов, Ю. М. Могаричев // Археологический альманах. - 2012. - № 28 : Древняя и средневековая Таврика : сб. ст., посвящ. 1800-летию города Судака. - С. 141-148. 
46. Соколова, И. В. Печати Георгия Цулы и события 1016 г. в Херсоне / И. В. Соколова // Палестинский сборник. - 1971. - Вып. 23 (86) : Византия и Восток. - С. 68-74.

47. Степаненко, В. П. Архонт и дука Тмутаракани в конце XI в. / В. П. Степаненко // XEP $\Sigma \Omega N O \Sigma$ ӨЕМАТА: «империя» и «полис». - Севастополь : СПД Арефьев, 2013. - С. 157-168.

48. Степаненко, В. П. Архонт Хазарии - стратиг Херсона? / В. П. Степаненко // Херсонесский сборник. - Севастополь : НПЦ «ЭКОСИ-Гидрофизика», 2011. - Вып. XVI. - C. 153-161.

49. Степаненко, В. П. Еще раз о локализации Хазарии в XI в. / В. П. Степаненко // Материалы по истории, археологии и этнографии Таврии. - 2014. Вып. ХІХ. - С. 368-378.

50. Степаненко, В. П. Некоторые вопросы истории Северного Причерноморья конца X - ХІ в. (по поводу книги А. Н. Слядзь «Византия и Русь. Опыт военно-политического взаимодействия в Крыму и Приазовье (XI - начало XII в.)») / В. П. Степаненко // Материалы по археологии, истории и этнографии Таврии. - Симферополь : НИЦ ИАК КФУ : ЦАИ БФ «Деметра», 2015. - Вып. ХХ. -С. 567-580.

51. Степаненко, В. П. Цула и Херсон в российской историографии XIX-XX вв. / В. П. Степаненко // Россия и мир: панорама исторического развития : сб. науч. ст., посвящ. 70-летию ист. фак. Урал. гос. ун-та им. А. М. Горького. - Екатеринбург : НПМП «Волот», 2008. - С. 27-35.

52. Степанова, Е. В. Византийские печати, найденные в Керчи и на Таманском полуострове, из собрания Н.П. Лихачева / Е. В. Степанова // Материалы по истории, археологии и этнографии Таврии. - Симферополь : КОИВ, 2007. - Вып. ХІІІ. - С. 364-374.

53. Степанова, Е. В. Находки печатей в Судаке / Е. В. Степанова // Житие Стефана Сурожского в контексте истории Крыма иконоборческого времени / Ю. М. Могаричев, А. В. Сазанов, Е. В. Степанова, А. К. Шапошников. - Симферополь : АнтиквА, 2009. - С. 175-192.

54. Степанова, Е. В. Печати Крыма из коллекции Н.П. Лихачева / Е. В. Степанова // Сто години от рождението на д-р Васил Хараланов (1907-2007) : юбил. сб. - Шумен : Регионален Исторически музей, 2008. - С. 187-194.

55. Хвольсон, Д. А. Известия о хозарах, буртаcax, болгарах, мадьярах, славянах и руссах Абу-Али Ахмеда бен Омар Ибн-Даста, арабского писателя начала Х века / Д. А. Хвольсон // Журнал Министерства народного просвещения. - 1868. - № 12. C. 657-771.

56. Цукерман, К. К вопросу о ранней истории фемы Херсона / К. Цукерман // Бахчисарайский историко-археологический сборник. - Симферополь : Таврия, 1997. - Вып. 1. - С. 312-323.
57. Чхаидзе, В. Н. Византийские печати из Тамани / В. Н. Чхаидзе. - М. : ИА РАН, 2015. - 202 с.

58. Чхаидзе, В. Н. Таматарха. Раннесредневековый город на Таманском полуострове / В. Н. Чхаидзе. - М. : ТАУС, 2008. - 328 с.

59. Чхаидзе, В. Н. Тмугаракань - владение Древнерусского государства в 80-е гг. Х в. -90-е гг. ХІ в. / В. Н. Чхаидзе // Сугдейский сборник. - Киев ; Судак : Горобец, 2012. - Вып. V. - C. 251-270.

60. Чхаидзе, В. Н. «Хазария» ХІ в.: к вопросу о локализации (по данным византийских моливдовулов) : препринт / В. Н. Чхаидзе. - М. : ИА РАН, 2016. - 44 с.

61. Chekin, L. S. Christian of Stavelot and the Conversion of Gog anf Magog. A Study of the NinthCentury Reference to Judaism Among the Khazars / L. S. Chekin // Rissia Mediaevalis. - 1998. - V. IX. P. 13-34.

62. Chkhaidze, V. Byzantine Lead Seals Addressed to Matarcha from the Sixth to the Twelfth Century/V. Chkhaidze // Byzantine and Rus' Seals. Kyiv : Sheremetievs' Museum, 2015. - P. 61-70.

63. Costantino Porfirogenito. The Thematubus / introd., testo critic, commento A. Pertusi. - Città del Vaticano: Biblioteca Apostolica Vaticano, 1952. - 212 p.

64. Darrouzès, J. Notitiae Episcopatum ecclesiae Constantinopolitanae / J. Darrouzès. - Paris : Institut Français d'Études Byzantines, 1981. - 522 p.

65. Dölger, F. Regesten der Kaiserurkunden des Oströmischen Reiches von 565-1453. 2.Teil. Regesten von 1025-1204 / F. Dölger. - München : Verlag C.H. Beck, 1995. -382 S.

66. Madgearu, A. The Place of Crimea and of the Kerch Strait in the Strategy of the Middle Byzantine Empire (7-12th Centuries) / A. Madgearu // Il Mar Nero. -2003. - Vol. V. - P. 193-208.

67. Miklosich, F. Acta et diplomata graeca medii aevi sacra et profana. T. 3. Acta et diplomata graeca res graecas italiasque illustrantia / F. Miklosich, I. Müller. - Vindobonae : Carolus Gerold, 1865 - 394 p.

68. Oikonomidès, N. Les listes de préséance byzantines des $\mathrm{IX}^{\mathrm{e}}$ et $\mathrm{X}^{\mathrm{e}}$ siècles / N. Oikonomidès. Paris : Centre National de la recherché scientifique, 1972. $-404 \mathrm{p}$.

69. Photii Patriarchae Constantinopolitani Epistulae et Amphilochia / Rec. B. Laourdas, L. G. Westerink. - Leipzig : BSB B.G. Teubner Verlagsgesellschaft, 1983. - Vol. 1. - 198 S.

70. Shepard, J. Closer Encounters with the Byzantine World: the Rus at the Straits of Kerch / J. Shepard // Pre-Modern Russia and Its World. Essays in Honor of T.S. Noonan. - Wiesbaden : Harrassowitz Verlag, 2006. - P. 17-77.

71. Zuckerman, C. On the Date of the Khazars' Conversion to Judaism and the Chronology of the Kings of the Rus Oleg and Igor / C. Zuckerman // Revue des études byzantines. - 1995. - Vol. 53. - P. 237-270. 
72. Zuckerman, C. Short Notes. Two Notes on the Early History of the Thema of Cherson / C. Zuckerman // Byzantine and Modern Greek Studies. - 1997. Vol. 21.- P. 211-222.

\section{REFERENCES}

1. Alekseenko N.A. Vizantiyskaya administratsiya na Bospore vo vtoroy polovine $\mathrm{X}$ v. (po dannym pamyatnikov sfragistiki) [Byzantine Administration on the Bosporus in the Second Half of the 10th Century (According to the Monuments Sphragistics)]. Materialy po arkheologii, istorii i etnografii Tavrii [Materials on Archaeology, History and Ethnography of Tauria], 2006, vol. 12, pp. 564-570.

2. Alekseenko N.A., Tsepkov Yu.A. Katepanat v Tavrike: legendarnye svidetelstva ili istoricheskie realii [Katepanikion in Taurica: Legendary Evidence or Historical Realities]. Khersonesskiy sbornik [Chersonesus Collection]. Sevastopol, SPD Arefyev Publ., 2012, vol. 17, pp. 7-17.

3. Alekseenko N.A. Molivdovuly bosporskikh episkopov iz Khersona [Molivdovuls of Bosporus Bishops From Cherson]. Problemy religiy stran chernomorsko-sredizemnomorskogo regiona [The Problems of Religions in the Countries of the Black Sea-Mediterranean Region]. Sevastopol, HGIKZ Publ., 2001, pp. 131-138.

4. Baranov I.A., Mayko V.V. Vizantiyskie monety serediny X v. iz Sugdei [Byzantine Coins of the Middle of the 10th Century From Sugdeja]. STRATUM plus, 1999, iss. 6, pp. 128-129.

5. Bolgov N.N. Bospor vizantiyskiy: ocherki istorii [Byzantine Bosporus: Essays on the History]. Problemy istorii, filologii i kultury, 1998, vol. 6, pp. 116-123.

6. Vinogradov A.Yu. Nadpis iz Tabana-dere: pyatsot let spustya [The Inscription From Tabanadere: 500 Years Later]. Antichnaya drevnost $i$ srednie veka [Antiquity and the Middle Ages], 2009, vol. 39, pp. 262-271.

7. Gadlo A.V. Predystoriya Priazovskoy Rusi. Ocherki istorii russkogo knyazheniya na Severnom Kavkaze [The Prehistory of Azov Russia. Essays on the History of Russian Reign in the North Caucasus]. Saint Petersburg, SPbGU Publ., 2004. 362 p.

8. Golb N., Pritsak O. Khazarsko-evreyskie dokumenty X veka [Khazarian Hebrew Documents of the Tenth Century]. Moscow; Jerusalem, Gesharim Publ., 1997. 240 p.

9. Jakson T.N., Konovalova I.G., Podosinov A.V., eds. Drevnyaya Rus v svete zarubezhnykh istochnikov: khrestomatiya. T.III. Vostochnye istochniki [Ancient Russia in the Light of the Foreign Sources: Anthology. Vol. 3. Eastern Sources]. Moscow, Russkiy
Fond Sodeystviya Obrazovaniyu i Nauke Publ., 2009. $264 \mathrm{p}$.

10. Zaybt N., Zaybt V. Pechati stratigov vizantiyskoy femy Kherson [The Seals of the Strategos of the Byzantine Theme of Cherson]. Antichnaya drevnost $i$ srednie veka [Antiquity and the Middle Ages], 1995, vol. 27: Byzantium and Middle-Ages Crimea,pp. 91-97.

11. Velikhanova N., ed. Ibn Khordadbekh. Kniga putey $i$ stran [Ibn Khordadbeh. The Book of the Ways and Countries]. Baku, Elm Publ., 1986. 428 p.

12. Kazhdan A.P. Vizantiyskiy podatnoy sborshchik na beregakh Kimmeriyskogo Bospora $\mathrm{v}$ kontse XII v. [The Byzantine Tax Collector on the Coast of the Cimmerian Bosporus at the End of the 12th Century]. Problemy obshchestvenno-politicheskoy istorii Rossii i slavyanskikh stran [The Problems of the Public and Political History of Russia and Slavic Countries]. Moscow, Izd-vo Vostochnoy literatury, 1963,pp. 93-101.

13. Kazhdan A.P. Neizvestnoe grecheskoe svidetelstvo o russko-vizantiyskikh otnosheniyakh v XII v. [Unknown Greek Testimony on RussianByzantine Relations in the 12th Century]. Feodalnaya Rossiya vo vsemirno-istoricheskom protsesse: sbornik statey, posvyashchennyy L.V. Cherepninu [Feudal Russia in the World-Historical Process: Collection of Papers Dedicated to L.V. Cherepnin]. Moscow, Nauka Publ., 1972, pp. 235-236.

14. Kokovtsov P.K. Evreysko-khazarskaya perepiska $v$ X veke [Jewish-Khazar Correspondence in the 10th Century]. Leningrad, Izd-vo AN SSSR, 1932. $134 \mathrm{p}$.

15. Konovalova I.G. Gorod Rosiya/Rusiya v XII v. [The Town of Rosia/Rusiya in the 12th Century]. Vizantiyskie ocherki [Byzantine Essays]. Saint Petersburg, Aleteya Publ., 2001, pp. 128-140.

16. Litavrin G.G., Novoseltsev A.P., eds. Konstantin Bagryanorodnyy. Ob upravlenii imperiey [Constantine Porphirogenitus. De administrando imperio]. Moscow, Nauka Publ., 1991. 496 p.

17. Kulakovskiy Yu.A. K istorii Bospora-Kerchi v XI-XII vv. [To the History of the Bosporus - Kerch in the 11th-12th Centuries]. Trudy XI Arkheologicheskogo syezda v Kieve v 1899 g. T. 2 [Proceedings of the 11th Archaeological Congress in Kiev in 1899. Vol. 2]. Moscow, Pechatnya A.I. Snegirevoy, 1902, pp. 132-133.

18. Latyshev V.V. Sbornik grecheskikh nadpisey khristianskikh vremen iz Yuzhnoy Rossii [Collection of Greek Inscriptions of Christian Times From the Southern Russia]. Saint Petersburg, Izd-vo Imp. AN, 1896. 143 p.

19. Litavrin G.G. Novye svedeniya o Severnom Prichernomorye (XII v.) [New Data on the Northern Black Sea Region (12th c.)]. Feodalnaya Rossiya vo 
vsemirno-istoricheskom protsesse. Sbornik statey, posvyashchennyy L.V. Cherepninu [Feudal Russia in World-Historical Process. Collection of Papers Dedicated to L.V. Cherepnin]. Moscow, Nauka Publ., 1972, pp. 237-242.

20. Mayko V.V. K voprosu o vydelenii srednevekovykh gorizontov Bospora vtoroy poloviny $\mathrm{X}$ - nachala XI vv. [On the Identification of the Medieval Cultural Layers of the Bosporus in the Second Half of the 10th - early 11th Centuries]. 175 let Kerchenskomu muzeyu drevnostey. Materialy mezhdunarodnoy konferentsii [175 Anniversary of Kerch Museum of Antiquities. Proceedings of the International Conference]. Kerch, KGIKZ Publ., 2001, pp. 93-96.

21. Mayko V.V. K voprosu o khazarakh na Bospore vo vtoroy polovine X v. [To the Question About Khazars on the Bosporus in the Second Half of the 10th Century]. Pantikapey - Bospor - Kerch 26 vekov drevney stolitsy [Pantikapeus - Bosporus Kerch - 26 Centuries of Ancient Capital]. Kerch, KGIKZ Publ., 2000, pp. 87-92.

22. Makarova T.I. Arkheologicheskie raskopki v Kerchi okolo tserkvi Ioanna Predtechi [Excavations in Kerch Near the Church of the John the Baptist]. Materialy po arkheologii, istorii i etnografii Tavrii [Materials on Archaeology, History and Ethnography of Tauria], 1998, vol. 6, pp. 344-393.

23. Makarova T.I. Bospor - Korchev po arkheologicheskim dannym [Bosporus-Kerch According to the Archaeological Data]. Vizantiyskaya Tavrika [Byzantine Taurica]. Kiev, Naukova Dumka Publ., 1991, pp. 121-146.

24. Makarova T.I. Krym v X - pervoy polovine XIII vv. Bospor - Korchev [Crimea in the 10th - First Half of the 13th Centuries. Bosporus - Kerch]. Arkheologiya. Krym, Severo-Vostochnoe Prichernomorye i Zakavkazye v epokhu srednevekovya. IVXIII veka [Archaeology. Crimea, the North-Eastern Black Sea Coast and the South Caucasus in the Middle Ages. 4th-13th Centuries]. Moscow, Nauka Publ, 2003, pp. 68-73.

25. Mogarichev Yu.M. O "Krymskoy Khazarii” v XI-XII vekakh [On "The Crimean Khazaria" in the 11th12th Centuries]. Knyazha doba: istoriya i kultura [The Kings' Time: History and Culture]. Lvov, NANU Publ., 2013, vol. 7, pp. 49-58.

26. Mokhov A.S. K prosopografii vizantiyskoy Tavriki v XI v.: Varda Duka [To the Prosopography of the Byzantine Taurica in the 11th Century: Varda Dukas]. I Bakhchisarayskie nauchnye chteniya pamyati E.V. Veymarna: tezisy dokladov $i$ soobshcheniy [1st Bakhchisarai Scientific Readings in Memory of E.V. Veimarn: Abstracts of Reports]. Bakhchysarai, BIKZ Publ., 2012, pp. 50-51.

27. Myts V.L., Adaksina S.B. Nakhodki zolotykh vizantiyskikh monet iz raskopok Alustona [The Finds of Golden Byzantine Coins From the Aluston Excavations]. STRATUM plus, 1999, iss. 6, pp. 123-127. 28. Nazarenko A.V. Drevnyaya Rus na mezhdunarodnykh putyakh: mezhdistsiplinarnye ocherki kulturnykh, torgovykh, politicheskikh svyazey IX-XII vv. [Ancient Russia on International Routes: Interdisciplinary Essays on Cultural, Trade and Political Communications in the 9th-12th Centuries]. Moscow, Yazyki russkoy kultury Publ., 2001. 784 p.

29. Naumenko V.E. Vizantiyskiy Bospor v X v.: politiko-administrativnyy aspekt [Byzantine Bosporus in the 10th Century: Political and Administrative Aspect]. Imperiya romeev vo vremeni i prostranstve: tsentr i periferiya: tezisy dokladov XXI Vserossiyskoy nauchnoy sessii vizantinistov [The Empire of the Romans in Time and Space: Center and Periphery. Abstracts of the 21st All-Russian Scientific Session of Byzantine Scholars]. Moscow; Belgorod, Epitsentr Publ., 2016, pp. 154-156.

30. Naumenko V.E. K voenno-politicheskoy istorii Tavriki X v.: russko-vizantiyskiy konflikt 935-941 gg. i tak nazyvaemyy "pokhod Pesakha" [To the Military and Political History of Taurica in the 10th Century: the Rus-Byzantine Conflict in 935-941 and the SoCalled "Campaign of Pesakh"]. Khazarskiy Almanakh, 2014, vol. 12, pp. 118-134.

31. Naumenko V.E. K voprosu o nazvanii i date uchrezhdeniya vizantiyskoy femy v Tavrike [On the Name and the Date of the Establishment of Byzantine Theme in Taurica]. Materialy po arkheologii, istorii $i$ etnografii Tavrii [Materials on Archaeology, History and Ethnography of Tauria], 1998, vol. 6, pp. 689-700.

32. Naumenko V.E., Ponomarev L.Y. K voprosu o territorii i arkheologicheskikh pamyatnikakh BosporaKerchi X-XII vv. [On the Territory and Archeological Monuments of the Bosporus-Kerch in the 10th-12th Centuries]. X Bosporskie chteniya "Bospor Kimmeriyskiy $i$ varvarskiy mir v period antichnosti $i$ srednevekovya. Aktualnye problemy" [10th Bosporan Readings. The Cimmerian Bosporus and Barbarian World in the Period of Antiquity and the Middle Ages. Topical Problems]. Kerch, KOIV NANU Publ., 2009, pp. 311-321.

33. Naumenko V.E. K voprosu o kharaktere vizantiysko-khazarskikh otnosheniy v kontse VIII seredine IX vv. [On the Nature of the Byzantine-Khazar Relations in the late 8th-mid 9th Centuries]. Problemy istorii, filologii, kultury, 2002, vol. 12, pp. 544-568.

34. Naumenko V.E., Ponomarev L.Yu. K diskussii o vremeni stroitelstva tserkvi Ioanna Predtechi v Kerchi: istoriograficheskiy ekskurs [To the Discussion About the Time of the Construction of the Church of the St. John the Baptist in Kerch: Historiographical Excursus]. XVII Bosporskie chteniya "Bospor Kimmeriyskiy $i$ varvarskiy mir v period antichnosti $i$ 
srednevekovya. Issledovateli i issledovaniya" [10th Bosporan Readings. The Cimmerian Bosporus and Barbarian World in the Period of Antiquity and the Middle Ages. Researcheres and Research]. Kerch, Demetra Publ., 2016, pp. 325-331.

35. Naumenko V.E. K diskussii o politikoadministrativnom statuse Bospora v X-XII vv. [To the Discussion About Political and Administrative Status of the Bosporus in the 10th-12th Centuries]. XXVII Chteniya pamyati chlena-korrespondenta AN SSSR V.T. Pashuto "Vostochnaya Evropa $v$ drevnosti $i$ srednevekovye. Gosudarstvennaya territoriya kak faktor politogeneza" [27th Readings in Memory of Corresponding Member of the USSR Academy of Sciences V.T. Pachuto "Eastern Europe in the Antiquity and in the Middle Ages. State Territory as a Factor of Political Genesis"]. Moscow, IVI RAN Publ., 2015, pp. 212-216.

36. Naumenko V.E., Ponomarev L.Yu. Kizucheniyu istoricheskoy topografii srednevekovoy Kerchi: vizantiyskaya kamennaya ikona iz "Novogo Karantina" [To the Study of the Historical Topography of Medieval Kerch: Byzantine Stone Icon From "New Quarantine"]. Antichnaya drevnost $i$ srednie veka [Antiquity and the MiddleAges], 2015, vol. 43, pp. 275-288.

37. Naumenko V.E., Ponomarev L.Yu. K istoricheskoy topografii Bospora X-XII vv.: ob obstoyatelstvakh nakhodki i mestopolozhenii tak nazyvaemoy "tserkvi Sheveleva" ("tserkvi 1833 g.") [To the Historical Topography of Bosporus in the 10th12th Centuries: About the Circumstances of the Discovery and the Location of the So-Called "Shevelev Church" ("The Church 1833")]. Narteks. Byzantina Ukrainensis [Nartex. Byzantina Ukrainensis]. Kharkiv, Maydan Publ., 2013, vol. 2, pp. 295-309.

38. Naumenko V.E. Nekotorye klyuchevye voprosy istorii Tavriki X-XI vv.: politikoadministrativnyy aspekt [Some Key Questions of the History of Taurica in the 10th-11th Centuries: Political and Administrative Aspects]. Antichnaya drevnost $i$ srednie veka [Antiquity and the Middle Ages], 2011, vol. 40, pp. 165-188.

39. Naumenko V.E. Ot femy Klimatov k feme Kherson: osobennosti vizantiyskoy voennoadministrativnoy modeli $\mathrm{v}$ Tavrike $\mathrm{v}$ seredine IX nachale X v. [From the Theme of Klimata to the Theme of Cherson: Characteristics of Byzantine Military and Administrative Model in Taurica in the Middle 9th Early 10th Centuries]. Drevneyshie gosudarstva Vostochnoy Evropy. 2014 god. Drevnyaya Rus $i$ srednevekovaya Evropa: vozniknovenie gosudarstv [The Ancient States of Eastern Europe. 2014. Old Rus and Medieval Europe: the Origin of States]. Moscow, Russkiy Fond Sodeystviya Obrazovaniyu i Nauke Publ., 2016, pp. 475-506.
40. Naumenko V.E. Tavrika v sisteme russkovizantiyskikh otnosheniy serediny X-XI vv. (istorikoarkheologicheskiy kommentariy) [Taurica in the System of Rus-Byzantine Relations of the Middle of the 10th-11th Centuries (Historical and Archaeological Commentary)]. XEP $\Sigma \Omega N O \Sigma$ $\Theta E M A T A:$ imperiya» $i$ «polis» [XEP $\Sigma \Omega N O \Sigma$ @EMATA: "Empire" and "Polis"]. Sevastopol, SPD Arefyev Publ., 2013, pp. 169-206.

41. Naumenko V.E., Ponomarev L. Yu. Khristianskie pamyatniki i topografiya Bospora X-XII vv. [Christian Monuments and the Topography of the Bosporus in the 10th-12th Centuries]. Klimentovskiy sbornik. Materialy VI Mezhdunarodnoy konferentsii "Tserkovnaya arkheologiya: Khersones - gorod svyatogo Klimenta» [St. Clement's Papers. Materials of the 6th International Conference "Church Archaeology: Chersonesus - the City of St. Clement"]. Sevastopol, Teleskop Publ., 2013, pp. 244-263.

42. Plakhonin A. Rus na Bospori v XII stolitti [Rus on the Bosporus in the 12th Century]. Krim v istorichnikh realiyakh Ukraini [Crimea in Historical Realities of Ukraine]. Kiev, Institut istorii NANU Publ., 2004, pp. 78-85.

43. Likhachev D.S., Romanov B.A., eds. Povest vremennykh let. Pt. I [The Russian Primary Chronicle. Part 1]. Moscow; Leningrad, Izd-vo AN SSSR, 1950. $406 \mathrm{p}$.

44. Ponomarev L.Yu., Beylin D.V., Beylina S.A. Kerchenskaya tserkov Ioanna Predtechi (istoriograficheskiy obzor) [Kerch Church of the St. John the Baptist (Review of the Historiography)]. Nauchnyy sbornik Kerchenskogo zapovednika [Scientific Collection of the Kerch Preserve]. Simferopol, BiznesInform Publ., 2014, vol. 4, pp. 272-306.

45. Sazanov A.V., Mogarichev Yu.M. K diskussii o tak nazyvaemom pokhode Pesakha v Krym: arkheologicheskiy aspekt [To the Discussion About the So-Called Campaign of Pesakh to Crimea: the Archaeological Aspect]. Arkheologicheskiy Almanakh, 2012, iss. 28: The Ancient and Medieval Taurica. Collection of Papers, Dedicated to the 1800 Anniversary of Sudak City, pp. 141-148.

46. Sokolova I.V. Pechati Georgiya Zuly i sobytiya 1016 g. v Khersone [The Seals of George Tsula and Events 1016 in Cherson]. Palestinskiy sbornik [Palestinian Collection], 1971, vol. 23 (86): Vizantiya i Vostok [Byzantium and the East], pp. 68-74.

47. Stepanenko V.P. Arkhont i duka Tmutarakani v kontse XI v. [Archon and Dukas of Tmutarakan in Late of XI Century]. XEP $\Sigma \Omega N O \Sigma \Theta E M A T A$ : «imperiya» $i$ "polis» [XEP $\Sigma \Omega N O \Sigma$ OEMATA: "Empire" and "Polis"]. Sevastopol, SPD Arefyev, 2013, pp. 157-168.

48. Stepanenko V.P. Arkhont Khazarii - stratig Khersona? [Is the Archon of Khazaria the Strategos of Cherson?]. Khersonesskiy sbornik [Chersonesus 
Collection]. Sevastopol, NPC "EKOSI-Gidrofizika" Publ., 2011, vol. 16, pp. 153-161.

49. Stepanenko V.P. Eshche raz o lokalizatsii Khazarii v XI v. [Once Again on the Problem of Khazaria Localization in the 11th Century]. Materialy po istorii, arkheologii i etnografii Tavrii [Materials on Archaeology, History and Ethnography of Tauria], 2014, vol. 19, pp. 368-378.

50. Stepanenko V.P. Nekotorye voprosy istorii Severnogo Prichernomorya kontsa X - XI vv. (po povodu knigi A.N. Slyadz "Vizantiya i Rus. Opyt voenno-politicheskogo vzaimodeystviya v Krymu i Priazovye (XI - nachalo XII vv.)") [Some Aspects of the Northern Black Sea History in the Late 10th - 11th Centuries (on A.N. Sliadz's Book Byzantium and Rus. The Experience of Military and Political Cooperation in Crimea and Azov Sea Littoral (11th - Early 12th Centuries)"]. Materialy po arkheologii, istorii $i$ etnografii Tavrii [Materials on Archaeology, History and Ethnography of Tauria], 2015, vol. 20, pp. 567-580.

51. Stepanenko V.P. Zula i Kherson v rossiyskoy istoriografii XIX-XX vv. [Tsula and Cherson in Russian Historiography of the 19th-20th Centuries]. Rossiya $i$ mir: panorama istoricheskogo razvitiya. Sbornik nauchnykh statey, posvyashchennykh 70-letiyu istoricheskogo fakulteta Uralskogo gosudarstvennogo universiteta im. A.M. Gorkogo [Russia and World: Panorama of Historical Development. Collection of Scientific Articles, Dedicated to the 70th Anniversary of the Historical Faculty of the Ural State University Named After A.M. Gorky]. Ekaterinburg, NPMP "Volot" Publ., 2008, pp. 27-35.

52. Stepanova E.V. Vizantiyskie pechati, naydennye v Kerchi i na Tamanskom poluostrove, iz sobraniya N.P. Likhacheva [Byzantine Seals Found in Kerch and the Taman Peninsula, From the Collection of N.P. Likhachev]. Materialy po istorii, arkheologii i etnografii Tavrii [Materials on Archaeology, History and Ethnography of Tauria], 2007, vol. 13, pp. 364-374.

53. Stepanova E.V. Nakhodki pechatey v Sudake [The Finds of Seals in Sudak]. Mogarichev Yu.M., Sazanov A.V., Stepanova E.V., Shaposhnikov A.K. Zhitie Stefana Surozhskogo v kontekste istorii Kryma ikonoborcheskogo vremeni [The Life of Stephen of Sougdaia Within the Context of the Crimean History in the Iconoclast Period]. Simferopol, AntikvA Publ., 2009, pp. 175-192.

54. Stepanova E.V. Pechati Kryma iz kollektsii N.P. Likhacheva [Seals of Crimea From the Collection of N.P. Likhachev]. Sto godini ot rozhdenieto na d-r Vasil Kharalanov (1907-2007). Yubileen sbornik [Jubilee Collection]. Shumen, Regionalen Istoricheski muzey Publ., 2008, pp. 187-194.

55. Khvolson D.A. Izvestiya o khozarakh, burtasakh, bolgarakh, madyarakh, slavyanakh i russakh Abu-Ali Akhmeda ben Omar Ibn-Dasta, arabskogo pisatelya nachala X veka [News about Khazars, Burtasas, Bulgarians, Magyars, Slavs and Russ by AbuAli Ahmed ben Omar Ibn-Dast, an Arab Writer of the Early 10th Century]. Zhurnal Ministerstva narodnogo prosveshcheniya, 1868 , iss. 12, pp. 657-771.

56. Zukerman K. K voprosu o ranney istorii femy Khersona [On the Early History of Cherson's Theme]. Bakhchisarayskiy istoriko-arkheologicheskiy sbornik [Bakhchysarai Historical and Archaeological Collection]. Simferopol, Tavriya Publ., 1997, vol. 1, pp. 312-323.

57. Chkhaidze V.N. Vizantiyskie pechati iz Tamani [Byzantine Seals From Taman]. Moscow, IA RAN Publ., 2015. 202 p.

58. Chkhaidze V.N. Tamatarkha. Rannesrednevekovyy gorod na Tamanskom poluostrove [Tamatarkha. The Early Medieval City on the Taman Peninsula]. Moscow, TAUS Publ., 2008. 328 p.

59. Chkhaidze V.N. Tmutarakan - vladenie Drevnerusskogo gosudarstva v 80-e gg. X v. -90 -e gg. XI v. [Tmutarakan - Possession of the Old Russian State in the 880s-1090s]. Sugdeyskiy sbornik [Sugdaia Collection]. Kiev; Sudak, Gorobets Publ., 2012, vol. 5, pp. 251-270.

60. Chkhaidze V.N. «Khazariya» XI veka: $k$ voprosu o lokalizatsii (po dannym vizantiyskikh molivdovulov) ["Khazaria" in the 11th Century: on the Localization (According to the Byzantine Molivdovuls)]. Moscow, IA RAN Publ., 2016. 44 p. (preprint).

61. Chekin L.S. Christian of Stavelot and the Conversion of Gog and Magog. A Study of the NinthCentury Reference to Judaism Among the Khazars. Russia Mediaevalis, 1998, vol. 9, pp. 13-34.

62. Chkhaidze V. Byzantine Lead Seals Addressed to Matarcha from the Sixth to the Twelfth Century. Byzantine and Rus Seals. Kiev, Sheremetievs' Museum, 2015, pp. 61-70.

63. Pertusi A., ed. Costantino Porfirogenito. De thematibus [Constantine Porphyrogenitus From Thematibus]. Città del Vaticano, Biblioteca Apostolica Vaticano, $1952.212 \mathrm{p}$.

64. Darrouzès J. Notitiae Episcopatum ecclesiae Constantinopolitanae [The Dioceses of the Church of Constantinople]. Paris, Institut Français d'études Byzantines, $1981.522 \mathrm{p}$.

65. Dölger F. Regesten der Kaiserurkunden des Oströmischen Reiches von 565-1453. 2. Teil. Regesten von 1025-1204. München, Verl. C.H. Beck, 1995. 382 p.

66. Madgearu A. The Place of Crimea and of the Kerch Strait in the Strategy of the Middle Byzantine Empire (7th - 12th Centuries). Il Mar Nero, 2003, vol. 5, pp. 193-208.

67. Miklosich F., Müller I. Acta et diplomata graeca medii aevi sacra et profana. T. 3. Acta et diplomata graeca res graecas italiasque illustrantia 


\section{ИСТОРИЯ, КУЛЬТУРА, ПРАВО В ВИЗАНТИЙСКИХ ПРОВИНЦИЯХ}

[Journal of the Sacred and the Profane, and the Passports of the Greeks in the Middle Ages. The Acts and the Passports of the Greeks]. Vindobonae, Carolus Gerold, 1865.394 p.

68. Oikonomidès N. Les listes de préséance byzantines des $I X^{e}$ et $X^{e}$ siècles. Paris, Centre National de la recherché scientifique, 1972. $404 \mathrm{p}$.

69. Laourdas B., Westerink L.G, eds. Photii Patriarchae Constantinopolitani Epistulae et Amphilochia. V.1. Leipzig, BSB B.G. Teubner Verlagsgesellschaft, 1983. 198 p.
70. Shepard J. Closer Encounters with the Byzantine World: the Rus at the Straits of Kerch. Pre-Modern Russia and Its World. Essays in Honor of T.S. Noonan. Wiesbaden, Harrassowitz Verl., 2006, pp. 17-77.

71. Zuckerman C. On the Date of the Khazars' Conversion to Judaism and the Chronology of the Kings of the Rus Oleg and Igor. Revue des études byzantines, 1995, vol. 53, pp. 237-270.

72. Zuckerman C. Short Notes. Two Notes on the Early History of the Theme of Cherson. Byzantine and Modern Greek Studies, 1997, vol. 21, pp. 211-222.

\section{Information About the Author}

Valeriy E. Naumenko, Associate Professor, Department of Ancient History and Middle Ages, Crimean Federal University named after V.I. Vernadsky, Prosp. Vernadskogo, 4, 295007 Republic of Crimea, Simferopol, Russian Federation, byzance@rambler.ru.

\section{Информация об авторе}

Валерий Евгеньевич Науменко, доцент кафедры истории древнего мира и средних веков, Крымский федеральный университет им. В.И. Вернадского, просп. Вернадского, 4, 295007, Республика Крым, г. Симферополь, Российская Федерация, byzance@rambler.ru. 